\title{
Pengembangan Bahan Ajar Bahasa Inggris Berbasis Kompetensi Kerja Untuk Mempersiapkan Peserta Didik Menempuh On The Job Training di Bagian Front Office Hotel
}

\author{
Andreas Aris Eko Mulyono ${ }^{15}$, Suharno ${ }^{16}$, Ahmad Arif Musadad ${ }^{17}$ \\ andreas.aris98@gmail.com
}

\begin{abstract}
Kebutuhan pembelajaran Bahasa Inggris profesi untuk peserta didik International Hotel Management School (IHS) teridentifikasi setelah hasil evaluasi bersama program On the Job Training (OJT) menunjukkan bahwa unjuk kerja yang diharapkan dari peserta IHS yang menempuh OJT di bagian Front Office hotel, tidak sesuai dengan apa yang ditunjukkan di lapangan. Berdasarkan hasil analisa terhadap kurikulum pendidikan IHS, didapati bahwa program-program pembelajaran Bahasa Inggris di IHS dikembangkan berdasarkan situasi atau keadaan di mana peserta didik membutuhkan kerampilan berkomunikasi dalam Bahasa Inggris sebagai bagian dari tuntutan pekerjaan mereka. Oleh karena itu analisis kebutuhan pembelajaran (Need Analysis), yaitu tahap peserta didik mengidentifikasi kebutuhan pembelajaran, menjadi tahap yang paling menentukan di dalam proses pengembangan bahan ajar. Penelitian ini bertujuan untuk: mengembangkan bahan ajar Bahasa Inggris berbasis kompetensi kerja untuk mempersiapkan peserta didik IHS menempuh OJT di bagian Front Office hotel, dan mengetahui efektifitas bahan ajar Bahasa Inggris berbasis kompetensi kerja dalam meningkatkan kompetensi kecakapan Berbahasa Inggris peserta didik/i IHS. Bahan ajar Bahasa Inggris berbasis kompetensi kerja yang dihasilkan di dalam penelitian ini dikaji dari dua aspek, yaitu: aspek efektivitas penggunaan bahan ajar, serta aspek kelayakan bahan ajar, yang meliputi kelayakan isi, kelayakan kebahasaan, kelayakan penyajian, dan kelayakan unsur dekoratif bahan ajar.
\end{abstract}

Kata Kunci: Pengembangan, Bahan Ajar, Bahasa Inggris untuk Kebutuhan Profesi,

\footnotetext{
${ }^{15}$ Alumni Magister Teknologi Pendidikan Universitas Sebelas Maret 


\section{PENDAHULUAN}

S

ebagai salah satu bahasa yang paling banyak digunakan dalam komunikasi internasional, Bahasa Inggris berkembang seiring dengan pertumbuhan industri pariwisata global. Hal ini membawa dampak langsung terhadap pengelolaan kegiatan pendidikan dan latihan di institusi pendidikan vokasi perhotelan dan pariwisata. Kegiatan pendidikan dan latihan tidak bisa lagi didominasi dengan program-program yang diarahkan untuk menyelesaikan pekerjaan dengan kekuatan fisik, namun juga membekali peserta didik dengan ketrampilan dan kompetensi, yang biasanya tidak dipelajari secara langsung di sekolah, yaitu kompetensi dalam membina komunikasi dengan orang lain dan lingkungan sekitarnya, yang salah satunya dibuktikan dengan kecakapan berkomunikasi baik secara lisan maupun tulisan, termasuk dengan menggunakan bahasa asing yang paling tinggi digunakan di sektor industri jasa perhotelan, yaitu Bahasa Inggris.

Suparman (2012) menyatakan bahwa kebutuhan adalah kesenjangan antara keadaan saat ini dibandingkan keadaan yang seharusnya. Setiap keadaan yang kurang dari yang semestinya, menunjukkan kebutuhan. Sementara itu, Morrison (2007) menyatakan bahwa kebutuhan adalah kesenjangan antara apa yang diharapkan dengan kenyataan yang terjadi di lapangan. Kebutuhan dan kesenjangan ini selanjutnya akan menciptakan kebutuhan pembelajaran.

Penelitian ini bertujuan untuk mengembangkan bahan ajar Bahasa Inggris berbasis kompetensi kerja untuk mempersiapkan peserta didik IHS menempuh OJT di bagian Front Office hotel. Dasar pengembangan bahan ajar ini adalah prestasi unjuk kerja trainee peserta didik IHS, khususnya mereka yang menempuh OJT di bagian Front Office hotel, yang dianggap belum bisa mengimbangi perkembangan dunia industri. Bahan ajar Bahasa Inggris berbasis kompetensi kerja yang dikembangkan di dalam penelitian ini memiliki karakteristik pengembangan sebagai berikut: (1) mengadopsi model pengembangan Dick and Carey (2009), (2) produk yang dihasilkan merupakan program English for Occupational Purposes (EOP), yang akan memfasilitasi kebutuhan pembelajaran Bahasa Inggris untuk profesi staff Front Office hotel, dan (3) merujuk pada Standar Kompetensi Kerja Nasional Indonesia (SKKNI).

Bahan ajar Bahasa Inggris berbasis kompetensi kerja yang dikembangkan di dalam penelitian ini mengadopsi model pengembangan Dick and Carey. Model pengembangan Dick and Carey diadopsi karena: (a) dianggap sebagai model pengembangan yang cocok untuk mengembangkan bahan ajar training dan pelatihan; (b) memiliki kejelasan di setiap langkah-langkahnya, sehingga mudah diikuti, khususnya bagi mereka yang belum berpengalaman dalam mengembangkan bahan ajar; (b) terdiri dari tahap-tahap yang teratur, terperinci, serta efektif dan efisien dalam pelaksanaan; (c) dianggap luwes atau fleksibel karena memiliki ruang untuk dilakukannya revisi, termasuk revisi pada tahap awal proses pengembangan; (d) memiliki komponen yang mencakup semua aspek yang dibutuhkan dalam suatu perencanaan pembelajaran.

Di ranah ilmu lingistik dan pendidikan Bahasa Inggris, bahan ajar Bahasa Inggris berbasis kompetensi kerja yang dikembangkan di dalam penelitian ini termasuk di dalam program English for Occupational Purposes (EOP), salah satu cabang dari English for Specific Purposes (ESP). Hutchinson \& Waters (1987) dalam Bojovic (2006) menyatakan bahwa program ESP adalah sebuah fenomena di dunia pendidikan Bahasa Inggris. Perkembangan program ESP ini lebih dikarenakan tiga karena faktor utama, yaitu (1) Berkembangnya kebutuhan pembelajaran Bahasa Inggris profesi di negara-negara tujuan investasi dan ekspansi teknologi perusahaan-perusahaan Amerika Serikat, pada era industrialisasi 
pasca perang dunia kedua, (2) Perkembangan ilmu linguistik, yang membawa perubahan mendasar terhadap kerangka pengembangan program pembelajaran Bahasa Inggris. Dalam hal ini, pembelajaran Bahasa Inggris difokuskan pada bagaimana Bahasa Inggris digunakan di dalam komunikasi. Sehingga program pembelajaran Bahasa Inggris dirancang sesuai dengan konteks di mana Bahasa Inggris akan digunakan; (3) Perkembangan metode pembelajaran Bahasa Inggris, yang memperhatikan aspek psikolinguistik seseorang, ketika mempelajari bahasa baru. Implikasinya, pembelajaran Bahasa Inggris untuk peserta didik dewasa, tidak lagi difokuskan pada bagaimana penyajian materi di kelas, namun ditekankan pada bagaimana peserta didik menguasai Bahasa Inggris.

Lebih jauh, Hutchinson \& Waters (1987) dalam Bojovic (2006) menyebutkan bahwa ada dua hal yang perlu ditekankan dari sebuah program ESP, adalah: (1) program ESP adalah sebuah pendekatan, dan (2) dasar pengembangan program ESP adalah alasan mengapa peserta didik perlu mempelajari Bahasa Inggris. Lebih jauh, Dudley-Evans (2001) dalam Chang (2006) merumuskan karakteristik absolut program ESP, yaitu: (1) program ESP memenuhi kebutuhan khusus peserta didik; (2) program ESP disusun berdasarkan metodologi dan konteks komunikasi khusus; dan (3) program ESP difokuskan pada pemahaman tata bahasa serta ungkapan kebahasaan, ketrampilan, konteks kebahasaan, dan genre yang sesuai dengan kegiatan kebahasaan.

Lebih jauh, Dudley-Evans (2001) dalam Chang (2006) merumuskan pula karakteristik variabel program ESP, yaitu: (1) program ESP berhubungan dan didesain untuk kebutuhan disiplin ilmu tertentu; (2) program ESP bisa menerapkan metodologi yang berbeda dengan metodologi yang digunakan dalam pembelajaran Bahasa Inggris umum; (3) program ESP dikembangkan untuk peserta didik dewasa; (4) program ESP pada umumnya didesain untuk peserta didik dengan ketrampilan berbahasa Inggris menengah atau lanjut; dan (5) Program ESP membutuhkan pengetahuan dasar para peserta didik.

Hutchinson \& Waters (1987) dalam Tahir (2012), membagi program ESP menjadi tiga kelompok berdasarkan disiplin ilmu dan wilayah profesional peserta didiknya, yaitu: (1) Bahasa Inggris untuk IImu Pengetahuan dan Teknologi (English for Science and Technology); (2) Bahasa Inggris untuk Ekonomi dan Bisnis (English for Business and Economics); dan (3) Bahasa Inggris untu Ilmu Sosial (English for Social Studies). Masing-masing wilayah kajian tersebut selanjutnya dibagi menjadi dua cabang lagi, yaitu; EAP dan EOP.

Program ESP dikembangkan berdasarkan kebutuhan peserta didik. Oleh karena itu, Needs Analysis atau analisis kebutuhan pembelajaran menjadi tahap paling awal sekaligus menentukan di dalam proses pengembangan bahan ajar ESP. Pakar linguistik dan praktisi pembelajaran Bahasa Inggris sepakat bahwa Need Analysis adalah inti dari pengembangan bahan ajar ESP. Iwai et.al (1999) dalam Songhori (2008) menyatakan bahwa istilah Need Analysis mengacu pada kegiatan mengumpulkan informasi yang akan digunakan sebagai dasar pengembangan kurikulum yang sesuai dengan kebutuhan pembelajaran.

Selain mengumpulkan dan menganalisa informasi dan data, Dickinson (1991) dalam Kusumoto (2008) mengungkapkan bahwa Need Analysis merupakan tahap mengidentifikasi dan merumuskan; (1) Needs (Kebutuhan), yaitu ketrampilan yang seharusnya dikuasai oleh peserta didik sesuai dengan apa yang dibutuhkan; (2) Wants (Keinginan), yaitu ketrampilan yang akan dijadikan prioritas utama bagi peserta didik jika mendapat kesempatan dan waktu; dan (3) Lack (Kesenjangan), yaitu perbedaan antara apa yang telah diterima, apa yang dikuasai saat ini, dan apa yang peserta didik harapkan untuk bisa mereka kuasai. 
Program ESP dikembangkan untuk peserta didik dewasa. Oleh karena itu, motivasi peserta didik akan menentukan keberhasilan sebuah pembelajaran program ESP. Hal ini sesuai Knowles (1999) dalam Tylor (2009) yang menguraikan enam asumsi mengenai peserta didik dewasa, yang selanjutnya menjadi dasar dalam merancang program pembelajaran untuk peserta didik dewasa. Asumsi-asumsi tersebut adalah sebagai berikut: (1) Peserta didik dewasa melihat diri mereka sebagai pribadi yang memiliki kebebasan, khususnya untuk mengambil keputusan-keputusan pribadi dalam hidup mereka, termasuk keputusan untuk mengikuti program pembelajaran; (2) Peserta didik dewasa selalu menggunakan latar belakang pengalaman hidup ke dalam proses pembelajaran yang mereka jalankan. Bahan ajar ESP semestinya mampu merefleksikan pengalaman yang akan diperoleh peserta didik, serta memberikan kesempatan kepada mereke untuk membandingkan aspek-aspek pembelajaran ESP dengan pengalaman-pengalaman yang telah mereka miliki sebelumnya; (3) Peserta didik dewasa bersedia belajar ketika mereka merasakan adanya kebutuhan mengetahui dan memiliki kemampuan atau ketrampilan tertentu agar mampu melakukan unjuk kerja secara lebih efektif dan memuaskan, (4) Peserta didik dewasa memasuki tahap belajar berbasis problem solving dan pengalaman hidup. Untuk itulah materi otentik dipilih dalam mengembangkan program ESP, (6) Peserta didik dewasa termotivasi untuk belajar karena adanya motivasi. Bahan ajar program ESP seharusnya dikembangkan berdasarkan konsep pengembangan atau penguatan motivasi intrinsik peserta didik, artinya mampu memperlihatkan bahwa bahan ajar program ESP tersebut akan memberi manfaat bagi peserta didik ketika mengimplementasikannya di lingkungan akademik atau tempat kerja mereka, and (7) Peserta didik dewasa cenderung mempertimbangkan manfaat yang bisa dan tidak akan mereka peroleh ketika memutuskan untuk mengikuti sebuah proses pembelajaran. Oleh karena itu, program ESP harus mampu mendefinisikan dengan jelas dan tegas bentuk konkret penetahuan dan kerampilan baru, yang bisa diperoleh oleh peserta didik dari proses pembelajaran yang mereka ikuti.

Burdová (2007) menyatakan bahwa mereka yang belajar EOP sebenarnya tidak tertarik mempelajari Bahasa Inggris, mereka menempuh pembelajaran Bahasa Inggris untuk bisa menyelesaikan tugas atau pekerjaan tertentu dengan menggunakan Bahasa Inggris. Bisa disimpulkan di sini, bahwa peserta didik program EOP adalah peserta didik dewasa, yang pernah menempuh pembelajaran Bahasa Inggris sebelumnya. Implikasinya adalah keberhasilan peserta didik dalam menempuh program pembelajaran EOP ini akan sangat dipengaruhi oleh motivasi belajar peserta didik. Dengan demikian, aspek motivasi peserta didik menjadi bahan pertimbangan di dalam pengembangan bahan ajar Bahasa Inggris berbasis kompetensi kerja. Hal ini diwujudkan didalam implementasi pendekatan ARCS (Attention-Relevance-Confidence-Satisfaction).

Bahan ajar Bahasa Inggris yang dikembangkan di dalam penelitian ini mengacu pada standard kompetensi kerja seperti yang tertuang di dalam Standar Kompetensi Kerja Nasional Indonesia (SKKNI). SKKNI adalah uraian kemampuan yang mencakup pengetahuan, keterampilan dan sikap kerja minimal yang harus dimiliki seseorang untuk menduduki jabatan tertentu sesuai dengan ketentuan peraturan perundang-undangan yang berlaku. SKKNI dirumuskan dan dikembangkan oleh Badan Nasional Sertifikasi Profesi (BNSP), yang dibentuk oleh presiden berdasarkan PP No. 23 tahun 2004. BNSP telah menyelesaikan SKKNI Pariwisata subsektor Hotel dan Restoran dan telah ditetapkan berdasarkan Keputusan Menteri Tenaga Kerja dan Transmigrasi nomor KEP.239/MEN/X/2004.

Penyusunan SKKNI Pariwisata subsektor Hotel dan Restoran ini bertujuan untuk; (1) memberikan informasi untuk pengembangan program kurikulum, dan berfunsgi sebagai acuan dalam penyelenggaraan pelatihan, serta penilaian dan sertifikasi; (2) menjadi rujukan yang membantu dalam 
rekruitmen tenaga kerja, membantu penilaian unjuk kerja, mengembangkan program pelatihan bagi karyawan berdasarkan kebutuhan, serta membuat uraian jabatan; (3) menjadi acuan dalam merumuskan paket-paket program sertifikasi sesuai dengan kualifikasi dan levelnya, dan dalam penyelenggaraan pelatihan, penilaian dan sertifikasi.

\section{METODE PENELITIAN}

Jenis penelitian yang dipakai adalah penelitian dan pengembangan atau research and development $(R \& D)$, dengan tujuan mengembangkan produk berupa paket bahan ajar Bahasa Inggris berbasis kompetensi kerja untuk mempersiapkan peserta didik menempuh OJT di bagian Front Office hotel. Metode penelitian pengembangan ini terdiri dari tiga tahap, yaitu: (1) Studi Pendahuluan, yang terdiri dari tahap-tahap: (a) mengidentifikasi tujuan pembelajaran, (b) melakukan analisis pembelajaran, dan (c) menganalisis karakteristik peserta didik dan konteks pembelajaran; (2) Pengembangan Model, yang terdiri dari: (a) Desain produk, (b) Uji Validasi produk, dan (c) Revisi produk; (3) Uji coba efektivitas desain dan Evaluasi sumatif produk. Penelitian pengembangan ini dilaksanakan di International Hotel Management School (IHS) Surakarta.

Jenis data yang diperoleh di tahap studi pendahuluan adalah data kualiatif. Data kualitatif ini merupakan hasil analisis kebutuhan pembelajaran serta analisis profil peserta didik yang akan menggunakan bahan ajar Bahasa Inggris berbasis kompetensi kerja yang dikembangkan. Data yang digunakan di tahap studi pendahuluan diperoleh dengan mengunakan instrumen interview dan studi dokumen. Di tahap studi pendahuluan ini, interview dilakukan terhadap staff Akademik IHS yang mengelola OJT. Sementara itu, studi dokumentasi difokuskan pada kajian terhadap data dan laporan pelaksanaan program OJT di IHS.

Jenis data yang diperoleh di tahap pengembangan model adalah data kualitatif. Data kualitatif ini merupakan data hasil validasi tim pakar/ahli pengembangan kurikulum dan bahan ajar, dan pakar pengembangan program ESP, hasil uji coba perorangan, dan uji kelompok kecil. Data yang digunakan di tahap pengembangan model diperoleh dengan mengunakan instrumen kuisioner. Data yang dikumpulkan dengan intrumen kuisioner tersebut berupa penilaian dan evaluasi, serta masukan dan saran terhadap hasil pengembangan bahan ajar. Selanjutnya data ini akan digunakan sebagai dasar dilakukannya revisi atau perbaikan terhadap bahan ajar tersebut agar menjadi produk akhir yang layak untuk dijadikan bahan ajar untuk kegiatan pembelajaran di IHS.

Jenis data yang diperoleh di tahap Uji efektifitas desain adalah data kuantitatif. Data kuantitatif ini berupa data hasil uji coba implementasi bahan ajar Bahasa Inggris berbasis kompetensi kerja yang telah dikembangkan, untuk mengukur efektfitas bahan ajar tersebut. Data yang dikumpulkan adalah data nilai pretest dan posttest peserta didik dari kelas eksperimen, yaitu kelompok peserta didik yang menempuh pembelajaran dengan bahan ajar baru, dan kelompok peserta didik dari kelas kontrol, yaitu kelompok peserta didik yang menempuh pembelajaran dengan bahan ajar lama, English for Hotel Operation. Teknik analisa data yang digunakan adalah uji t berpasangan.

\section{HASIL PENGEMBANGAN}

Produk pengembangan penelitian berupa Bahan ajar Bahasa Inggris berbasis kompetensi kerja ini terdiri dari 13 unit materi, yang merujuk pada Standar Kompetensi Kerja Nasional Indonesia (SKKNI) 
Pariwisata subsektor Hotel dan Restoran, bidang kompetensi English Proficiency dan bidang kecakapan Front Office. Bidang kompetensi English Proficiency menjadi pedoman dalam menetapkan aspek dan ruang lingkup ketrampilan berbahasa yang menjadi fokus pengembangan bahan ajar, sementara bidang kecakapan Front Office menjadi pedoman dalam menentukan konteks situasional di mana komunikasi dalam Bahasa Inggris akan dilakukan dan terjadi.

Struktur penyajian bahan ajar tersebut adalah: (1) Judul Unit, yang menggunakan ungkapan kebahasaan yang muncul di unit bersangkutan; (2) Kegiatan Pra Pembelajaran, meliputi: (a) bagian yang mendeskripsikan cakupan materi dan tujuan pembelajaran, yang diberi judul Snapshot! dan (b) bagian dengan ilustrasi foto, kosa kata baru, dan daftar pertanyaan sebagai bahan diskusi awal, sebelum masuk ke materi inti. Bagian ini diberi judul, Let's Start; (3) Kegiatan Pembelajaran, yang meliputi: (a) Conversation, berisi contoh-contoh percakapan; (b) Language Focus, berisi pembahasan mengenai ungkapan kebahasaan dan konstruksi kalimat, sesuai dengan topik bahasan, disertai rangkaian latihanlatihan terpandu; (c) Reading, berisi teks bacaan serta latihan-latihan and (d) Word Power, berisi kegiatan latihan yang bertujuan untuk meningkatkan perbendaharaan kosa kata peserta didik; dan (4) Kegiatan evaluasi pembelajaran, yang diberi judul Work Out!

Selain unit-unit materi, bahan ajar Bahasa Inggris berbasis kompetensi kerja juga memiliki lima unit evaluasi, yang disisipkan diantara unit-unit materi inti. Unit-unit evaluasi ini terdiri dari lima bagian, dengan struktur penyajian sebagai berikut; (1) Latihan penggunaan ungkapan kebahasaan diberi judul What do you say? (2) Latihan tata bahasa diberi judul Grammar Point, (3) Latihan kosa kata diberi judul Word Chest, (4) Latihan percakapan terpandu diberi judul Act It Out, dan (5) Latihan percakapan dengan pengembangan diberi judul Follow Up Activities. Selain itu, bahan ajar Bahasa Inggris berbasis kompetensi kerja ini juga memiliki 1 unit tambahan yang berisi daftar ungkapan-ungkapan kebahasaan dasar yang digunakan di dalam komunikasi sehari-hari, yang akan muncul secara berulang di dalam bahan ajar Bahasa Inggris berbasis kompetensi kerja.

Bahan ajar Bahasa Inggris berbasis kompetensi kerja yang dikembangkan di dalam penelitian ini melalui rangakaian uji validitas dan uji coba sesuai dengan tahapan-tahapan dalam model pengembangan Dick and Carey, yaitu Uji/Validitas Pakar, Uji Coba kelompok Perorangan/Satu-satu, Uji Coba Kelompok Kecil. Rangkaian uji validitas dan uji coba ini dilaksanakan untuk mengevaluasi dari semua aspek pengembangan bahan ajar, sebelum dilakukan uji efektifitas, di kelas yang sesungguhnya.

Berdasarkan hasil uji/validasi pakar, produk bahan ajar Bahasa Inggris berbasis kompetensi kerja yang dihasilkan di dalam penelitian ini dinilai telah memenuhi seluruh aspek teoritis pengembangan bahan ajar program pembelajaran ESP/EOP. Sementara itu, hasil Uji Coba Perorangan/Satu-satu, dan Uji Coba Kelompok Kecil, menunjukkan adanya temuan-temuan yang sebagian diantaranya perlu ditindaklanjuti dengan proses revisi terhadap bahan ajar yang dihasilkan. Beberapa temuan tidak ditindaklanjuti dengan tahapan revisi oleh karena temuan tersebut tidak bersifat substansial, yang akan memberi pengaruh signifikan terhadap kualitas bahan ajar yang dihasilkan.

Di dalam tahap uji efektifitas desain, masih terdapat temuan-temuan yang perlu dipertimbangkan sebagai materi revisi akhir sebelum bahan ajar Bahasa Inggris berbasis kompetensi kerja didesiminasikan. Berdasarkan hasil uji efektifitas desain ini, diperoleh hasil sebagai berikut: (1) Terdapat perbedaan signifikan antara nilai Pretest dan Post Tests peserta didik, yang menempuh pembelajaran Bahasa Inggris dengan bahan ajar baru, pada uji ketrampilan berbahasa Inggris di bidang profesi Front Office Hotel; (2) Perbandingan rata-rata (Mean) nilai Posttest kelompok kontrol dengan kelompok 
eksperimen, yaitu 75,43 untuk kelompok kontrol dan 76,63, untuk kelompok eksperimen, dan (3) Terdapat perbedaan signifikan antara nilai Pretest dan nilai Posttest pada uji ketrampilan berbahasa Inggris di bidang profesi Front Office Hotel pada kelompok eksperimen terhadap kelompok kontrol.

Berdasarkan hasil Uji kelayakan bahan ajar Bahasa Inggris berbasis kompetensi kerja, berdasarkan penilaian pada 4 komponen uji kelayakan, diperoleh hasil sebagai berikut: (1) isi 82\%, (2) kebahasaan $87 \%$, (3) penyajian $78 \%$, (4) unsur-unsur dekoratif $75 \%$, dan rata-rata keempat komponen ini adalah $80,5 \%$. Artinya, bahan ajar Bahasa Inggris berbasis kompetensi kerja yang dihasilkan di dalam penelitian ini layak untuk digunakan sebagai bahan ajar untuk mempersiapkan peserta didik IHS menempuh OJT di bagian Front Office Hotel di International Hotel Management School (IHS).

\section{PEMBAHASAN}

Langkah pengembangan bahan ajar Bahasa Inggris berbasis kompetensi kerja, yang dihasilkan di dalam penelitian ini mengadopsi 10 (sepuluh) langkah pengembangan model Dick and Carey (2009), dengan tujuan agar produk yang dihasilkan bisa menunjang proses pembelajaran yang efektif, yaitu proses pembelajaran yang memfasilitasi peserta didik mempelajari dan melatih pengetahuan, ketrampilan dan sikap yang diharapkan. Hal ini sesuai dengan Raiser dan Dick (1996) dalam Aytekin Isman (2011) yang menyatakan bahwa semua faktor di dalam proses pebelajaran harus ditetapkan dengan baik, agar menghasilkan sebuah program pembelajaran yang efektif akan memotivasi peserta didik.

Bahan ajar Bahasa Inggris berbasis kompetensi kerja yang dikembangkan di dalam adalah sebuah program pembelajaran English for Occupational Purposes (EOP). Artinya, Bahasa Inggris yang dipelajari hanya akan berfungsi secara efektif di dalam konteks komunikasi di bidang profesi atau pekerjaan sebagai staff Front Office Hotel. Konsep kebermanfaatan yang terbatas sebuah proses pembelajaran Bahasa Inggris ini sesuai dengan Mackay and Mountford (1988) dalam Tahir (2013) yang menyatakan bahwa peserta didik program pembelajaran EOP ini relatif akan mengalami kesulitan untuk melakukan komunikasi secara efektif di luar konteks dan lingkungan komunikasi di mana bahasa tersebut dipergunakan.

Untuk mengetahui batasan-batasan kebahasaan tersebut, maka pengembangan bahan ajar Bahasa Inggris berbasis kompetensi kerja di dalam penelitian ini diawali dengan tahap Need Analysis atau analisis kebutuhan pembelajaran. Need Analysis ini secara khusus bertujuan untuk mengidentifikasi ruang lingkup materi yang akan dipelajari. Brown (1995) dalam Kusumoto (2008) menjabarkan ruang lingkup materi ini meliputi rumusan daftar tujuan pembelajaran, rancangan kegiatan pembelajaran di kelas, dan strategi evaluasi.

Untuk memastikan bahwa tujuan pengembangan program pembelajaran sesuai dengan kurikulum, silabus, dan bahan ajar yang dihasilkan, maka Need Nalysis harus mempertimbangkan dengan cermat subyek Needs Analysis ini. Di dalam penelitian ini, subyek dari Need Analysis adalah peserta didik IHS, yang akan menggunakan produk yang dihasilkan. Peserta didik IHS diharapkan mampu mengidentifikasi kapan, apa, dan bagaimana mereka akan belajar. Hal ini sesuai dengan Carver (1983) dalam Bojovic (2006) yang menyatakan bahwa untuk bisa memenuhi fungsi dan kebutuhan, Need Analysis harus mengedepankan kebebasan calon peserta didik 
Pengembangan dan penyajian program pembelajaran Bahasa Inggris berbasis kompetensi kerja di IHS, tidak bisa didasarkan pada analisis kebutuhan pembelajaran yang melibatkan peserta didik. Hal ini karena peserta didik IHS tidak kompeten dalam mengidentifikasi kebutuhan belajar mereka. Dalam hal ini, peserta didik IHS tidak memiliki pengetahuan yang memadahi mengenai kebutuhan kecakapan berkomunikasi dalam Bahasa Inggris yang akan menjadi bagian dari tuntutan pekerjaan mereka.

Berdasarkan profil calon peserta didik, Need Analysis adalah tahap mengumpulkan data dan informasi yang relevan, untuk dijadikan rujukan dalam mengidentifikasi dan merumuskan kebutuhan pembelajaran, yang menjadi dasar pengembangan bahan ajar yang dibutuhkan peserta didik. Hal ini sesuai dengan Iwai et.al (1999) dalam Songhori (2008) menyatakan bahwa Need Analysis merujuk pada kegiatan mengumpulkan informsi yang akan digunakan sebagai dasar pengembangan kurikulum yang sesuai dengan kebutuhan pembelajaran.

Oleh karena keikutsertaan dan keberhasilan peserta didik IHS di dalam menempuh program pembelajaran Bahasa Inggris akan menentukan tahap OJT, maka dasar pengembangan program pembelajaran Bahasa Inggris berbasis kompetensi kerja adalah standar kecakapan berkomunikasi Bahasa Inggris yang merujuk pada norma atau standar kompetensi kerja, yang ditetapkan oleh institusi atau lembaga yang memiliki otoritas untuk menyusun dan menetapkan standar kompetensi kerja tersebut. Merujuk pada norma dan standar kompetensi kerja di dalam pengembangan bahan ajar Bahasa Inggris berbasis kompetensi kerja telah selaras dengan Kepmen No. 239/MEN/X/2004 tentang SKKNI Pariwisata subsektor Hotel dan Restauran.

Dengan merujuk pada standar kompetensi kerja (SKKNI), program pembelajaran Bahasa Inggris yang dikembangkan akan relevan dan benar-benar mendukung persiapan peserta didik memasuki dunia kerja, sesuai dengan pilihan profesi yang ingin mereka tekuni. Selain itu, kurikulum, silabus, dan bahan ajar yang dihasilkan akan benar-benar membekali peserta didik IHS dengan kecakapan berkomunikasi dalam Bahasa Inggris sesuai dengan kompetensi kerja yang dibutuhkan untuk bisa berada di posisi dan jabatan tertentu di hotel, serta melaksanakan suatu tugas sesuai dengan posisi atau jabatan itu.

\section{SIMPULAN DAN SARAN}

Program pembelajaran Bahasa Inggris yang dikembagkan untuk memenuhi kebutuhan pembelajaran khusus disebut English for Specific Purposes (ESP). Adapun program pembelajaran Bahasa Inggris yang digunakan di IHS termasuk program English for Occupational Purposes (EOP), karena karena dikembangkan berdasarkan situasi atau keadaan di mana peserta didik membutuhkan kerampilan berkomunikasi dalam Bahasa Inggris sebagai bagian tuntutan pekerjaan mereka.

Program ESP/EOP dikembangkan berdasarkan kebutuhan peserta didik. Sehingga, Needs Analysis menjadi tahap paling awal sekaligus menentukan di dalam proses pengembangan bahan ajar ESP/EOP. Namun, karena peserta didik IHS tidak cukup kompeten dalam mengidentifikasi dan merumuskan kebutuhan pembelajaran mereka, maka pengembangan bahan ajar Bahasa Inggris berbasis kompetensi kerja di dalam penelitian ini adalah standar kompetensi kerja yang saat ini ada dan berlaku di Indonesia, yaitu sistem standarisasi kompetensi kerja yang ditetapkan oleh Badan Nasional Sertifikasi Profesi (BNSP), yaitu Standar Kompetensi Kerja Nasional Indonesia (SKKNI), maka dasar pengembangan program pembelajaran Bahasa Inggris di IHS adalah Standar Kompetensi Kerja Nasional Indonesia (SKKNI) subsektor Hotel dan Restoran, khususnya bidang kompetensi English Profeciency dan Front Office. 
Model pengembangan Dick and Carey diadopsi sebagai instrumen konseptual untuk menganalisa, merancang, serta mengevaluasi bahan ajar yang dikembangkan. Produk akhir dari penelitian pengembangan ini adalah bahan ajar Bahasa Inggris berbasis kompetensi kerja, yang ditujukan untuk mempersiapkan peserta didik IHS untuk menempuh OJT di bagian Front Office hotel.

Hasil uji efektifitas produk bahan ajar dengan instrumen Uji - T menunjukkan bahwa bahan ajar Bahasa Inggris berbasis kompetensi kerja, terbukti efektif. Sementara itu, hasil uji kelayakan produk, yang meliputi kelayakan isi, kelayakan kebahasaan, kelayakan penyajian, dan kelayakan unsur dekoratif bahan ajar, bahan ajar Bahasa Inggris berbasis kompetensi kerja yang dihasilkan dianggap layak untuk digunakan.

Berdasarkan hasil penelitian tersebut dapat disarankan: (1) Untuk Insternational Hotel Management School, (a) Bahan ajar Bahasa Inggris berbasis kompetensi kerja yang sudah disusun agar bisa digunakan dalam proses pembelajaran Bahasa Inggris di IHS untuk mempersiapkan peserta didik IHS menempuh On the Job Traning di bagian Front Office Hotel; (b) Bagian kurikulum dan perencanaan program di IHS diharapkan melakukan evaluasi secara berkala terhadap implementasi bahan ajar Bahasa Inggris berbasis kompetensi kerja ini, untuk kebutuhan penyempurnaan terhadap bahan ajar Bahasa Inggris berbasis kompetensi kerja ini; (c) Bagian kurikulum dan perencanaan program di IHS perlu mempertimbangkan untuk melakukan pengembangan bahan ajar Bahasa Inggris berbasis kompetensi kerja untuk bidang profesi lain di sektor industri perhotelan. Selain itu, perlu juga melakukan peninjauan dan pembenahan secukupnya terhadap terhadap bahan ajar diimplementasikan di IHS, untuk memastikan bahwa pijakan teoritis pengembangan bahan ajar tersebut sesuai dengan tujuan yang hendak dicapai melalui proses pembelajaran dengan menggunakan bahan ajar yang dihasilkan. Akhirnya, (2) perlu dilakukan penelitian lanjutan untuk mengembangkan dan merumuskan strategi baru dalam mengembangakan bahan ajar berbasis kompetensi kerja dengan model yang lebih bervariasi karena pengembangan bahan ajar Bahasa Inggris berbasis kompetensi kerja yang dihasilkan di dalam penelitian ini merupakan sebuah produk yang dihasilkan oleh salah satu dari sekian banyak model pengembangan bahan ajar.

\section{DAFTAR PUSTAKA}

Suparman, M. A. (2012). Desain Intruksional Modern. Jakarta: Penerbit Erlangga.

Isman, A. (2011). Instructional Design in Education: New Model. The Turkish Online Journal of Educational Technology, 10(1).

Bojovic, M. M. A. (2006). Teaching Foreign Language for Specific Purposes: Teacher Development. hlm 489 - 493 dalam Mateja Brejc (ed.) disampaikan pada 31st Annual ATEE Conference, 21 - 25 Oktober 2006.

Chang, Nan-Yu. (2009). A Need Analysisof Applying an ESP Program for Hotel Employees. Yu Da Academic Journal, 21, hlm. 1 - 10.

Departemen Tenaga Kerja dan Transmigrasi Republik Indonesia. 2004. Lampiran Keputusan Menteri Tenaga Kerja dan Transmigrasi Republik Indonesia nomor KEP.239/MEN/X/2004 tentang Standard Kompetensi Kerja Nasional Indonesia (SKKNI) Pariwisata subsektor Hotel dan Restoran. Departemen Tenaga Kerja dan Transmigrasi.

Dick, W., Carey, L. \& Carey, J. O. (2009). The Systematic Design of Instruction. Upper Saddle River, NJ: pearson

Morrison, G., Ross, R., Kemp, J. (2007). Designing Effective Indtruction: $5^{\text {th }}$ Edition. New York: John Wiley \& Sons, Inc. 